\title{
Kurt Vonnegut's Slaughterhouse-Five: A Postmodernist Study
}

\author{
Noorbakhsh Hooti \\ English Department, Faculty of Arts, Razi University, Kermanshah, Iran \\ Email: nhooti@yahoo.com \\ Vahid Omrani \\ English Department, Faculty of Arts, Lorestan University, Khoram Abad, Iran \\ Email: vahidomrani@yahoo.com
}

\begin{abstract}
This study tries to analyze Kurt Vonnegut's "Slaughterhouse-Five" from a postmodernist point of view. The concepts used are mostly from a range of literary and psychological resources. Vonnegut applies some narrative techniques which closely match those of the postmodernist diegetic process. The narrative has a potentially representative content which opens one's horizons toward new sources of meaning and conceptual interpretation. The focal point, in this study, is to examine the ontological level, stream of narration, fragmentation, parody and irony to see how tangibly these terms agree with the very context of the abovementioned novel and to find out whether the purely abstract terms extracted from postmodernist theory can be concretized in a practical form. Furthermore, this study aims at scrutinizing in detail the frequency and the possibility of the postmodernist narrative elements in the very fabric and texture of fictional narrative in general.
\end{abstract}

Index Terms-postmodernism, Slaughterhouse -Five, metanarrative, Vonnegut

\section{Introduction}

The study starts with a brief introduction of Postmodernism, and a short summary of Slaughterhouse-Five, which is followed by the postmodernist analysis of Slaughterhouse-Five, and finally the study comes up with its conclusion.

\section{POSTMODERNISM}

A great deal of postmodernist theory depends on the maintenance of a skeptical attitude: and here the philosopher Jean-François Lyotard's contribution is essential. He argued in his La condition postmoderne (published in French in 1979, in English in 1984) that we now live in an era in which legitimizing 'master narratives' are in crisis and in decline. These narratives are contained in or implied by major philosophies, such as Kantianism, Hegelianism, and Marxism, which argue that history is progressive, that knowledge can liberate us, and that all knowledge has a secret unity. The two main narratives Lyotard is attacking are those of the progressive emancipation of humanity - from Christian redemption to Marxist Utopia - and that of the triumph of science. Lyotard considers that such doctrines have 'lost their credibility' since the Second World War. He (1984) defines postmodern as incredulity towards metanarratives.

These metanarratives traditionally serve to give cultural practices some form of legitimation or authority. (The legitimation of Marxist or Freudian theories thus would stem from their claim, not widely accepted by now, that they are based on the principles or metanarrative of science.) Another example of this would be the textbook history of the writing of the Constitution of the United States, by the Founding Fathers, along with its subsequent legislative enactments. This grand historical narrative with its constitutional 'founding principles' is still very much a going concern in current disputes in the United States about the limits of free speech, the right to abortion, and the right of American private citizens to bear arms. Another simple example of metanarrative is the Marxist belief in the predestined and privileged function of the proletariat, with the party as its ally, in bringing about a revolution, and in the Utopia which is supposed to follow, when 'the state has withered away'. In the period since 1945, the governments of many formerly colonized territories have developed similarly would-be masterful political narratives about the history of nationalist struggle. It is difficult to avoid such narratives, and nearly all nation-states have them.

Although there are good liberal reasons for being against such 'grand narratives' (on the grounds that they do not allow for disputes about value, and often enough lead to totalitarian persecution), the plausibility of Lyotard's claim for the decline of metanarratives in the late 20th century ultimately depends upon an appeal to the cultural condition of an intellectual minority. The general sociological claim that such narratives are in decline in our period looks pretty thin, even after the collapse of state-sponsored Marxism in the West, because allegiances to large-scale, totalizing religious and nationalist beliefs are currently responsible for so much repression, violence, and war - in Northern Ireland, Serbia, the Middle East, and elsewhere. (Postmodernists tend not to be well informed about current practices in science and 
religion.) It is obvious to any reader of the newspapers that men and women are still more or less willing to kill one another in the name of grand narratives every day. Indeed, the reason why academic postmodernists seemed so secure in their hostile analysis of the American and European societies around them in the 1970s may well have derived from the fact that these societies were not torn apart by contrary ideologies. Some thoughts about the rival claims of Islam and Judaism in the Middle East, or of Marxism and the democratic process in Eastern Europe, might have led to different conclusions. But the skepticism about commitments to master narratives promoted by Lyotard, and echoed by Derrida and many other postmodernists, had a strong appeal to a generation brought up in Western democracies. They were liberated to some degree from theology by existentialism, impressed by the resistance offered to capitalism and the military-industrial complex in 1968, suspicious of American 'imperialist' pretensions, and perhaps more importantly needed to escape the deadeningly Manichaean ideological platitudes of the Cold War period.

The result was that the basic attitude of postmodernists was skepticism about the claims of any kind of overall, totalizing explanation. Lyotard was not alone in seeing the intellectual's task as one of 'resistance', even to 'consensus', which 'has become an outmoded and suspect value'. Postmodernists responded to this view, partly for the good reason that by doing so they could side with those who didn't 'fit' into the larger stories - the subordinated and the marginalized - against those with the power to disseminate the master narratives. Many postmodernist intellectuals thus saw themselves as avant-garde and bravely dissentient. This heralded a pluralist age, in which, as we shall see, even the arguments of scientists and historians are to be seen as no more than quasi narratives which compete with all the others for acceptance. They have no unique or reliable fit to the world, no certain correspondence with reality. They are just another form of fiction.

Of course, an opposition to such narratives (particularly holistic or totalitarian ones) is an absolutely traditional liberal concern. Much significant postmodernist writing has therefore turned on articulating this kind of skepticism for essentially liberal ends, as for example in the work of Edward Said, who in his Orientalism (1978) attempted to show the distorting effects of the projection of the Western grand narrative of imperialism upon Oriental societies. For the imperialist saw himself as the representative of a rational, ordered, peaceful, and law-abiding framework, and defined the Orient as the opposite of this (for example, as the 'muddle' Forster found in A Passage to India), and had the confidence that his representation of 'them' - his narrative of 'Orientalism' - would prevail. The grand imperial story of progressive development was superimposed on a merely local - and, what is more, 'deviant' - Oriental practice. In all this Said follows Foucault, and the Euhemerism of the Greeks and of Nietzsche, in believing that such imposing political grand narratives are at best mystificatory attempts to keep some social groups in power, and others out of it. As Said notes, when Flaubert slept with an Egyptian courtesan, Kuchuk Hanem, he wrote to Louise Colet that 'the oriental woman is no more than a machine; she makes no distinction between one man and another man'. In so doing (and in his subsequent novels) he 'produced a widely influential model of the Oriental woman'. But within this influential narrrative, 'she never spoke of herself, never represented her emotions, presence or history.' We can imagine how different her own account might indeed have been, but the two frameworks for narrative, Flaubert's and -Kuchuk Hanem's, seem to be culturally incommensurable; hence a typical postmodernist conclusion, that universal truth is impossible, and relativism is our fate.

\section{ARGUMENT}

\section{A. Slaughterhouse-Five}

This novel does not follow the realistic or modernist trends and defies the conventional forms of plot. As a postmodernist novel it is created in fragmented forms. The fragments include the life of Billy based on Vonnegut's life, his fictionalized experience of fire-bombing in Dresden and the Tralfamadorian plot as in confrontation with life on earth .The fragmented parts of Billy Pilgrim, life in the different sections are linked through time-travels .Billy Pilgrim was an infantry scout during world war II and becomes an optometrist after the war. The novel begins with Billy serving as an American soldier in World War II. He is captured by Germans and is taken to Dresden .The city is destroyed by an air raid, but Billy and one hundred soldiers survive the raid. Then he returns to Ilium, New York and becomes a successful optometrist; he marries Valencia, the daughter of a rich optometrist, he has two children, Barbara and Robert; .Barbara marries an optometrist and Robert becomes a member of the famous Green Berets in Vietnam. On the night of his daughter's wedding, Billy is kidnapped by some aliens and is taken to another planet called Tralfamadore where he is mated with an Earthling movie, star Montana Wildhack .After returning to earth, he continues practicing optometry. On his way to a convention, he has a plane crash and is taken to hospital .After his recovery, he still talks about Tralfamadorians and suffers from the nervous breakdown of his experience in war. Consequently, everybody including his own daughter accuses him of insanity, He finally decides to travel to New York city and appear on a radio program to talk about life on Tralfamadore and their wisdom.

\section{B. The Ontological Dimension of Kurt Vonnegut's Slaughterhouse-Five}

In analyzing, Slaughter-house Five, what we come across is mainly concerned with the "worlds in confrontation" (McHale, 1983, p. 60). In fact, the world of Dresden is "in confrontation" with Tralfamadore as an imaginary world where the norms of "Earthlings are violated" (p.10). This aspect of Slaughter-House Five does not deal with resolutions but ironically instigates some philosophical problematizations in the eye of the readers. 
As was mentioned before, there must be a "psychological conceivability" in the postmodernist fiction to convey the message of ontology to readers. This aim is remarkably achieved through what McHale calls "transworld identity". In Slaughter-House Five, Billy pilgrim shoulders the responsibility in gaining the goal as a "transworld identity". Billy was "taken through a time warp" (p.26) by the Tralfamadorians" so that he could be on Tralfamadore for years, and still be away from Earth for only a microsecond". In other words, we, readers encounter "a confrontation between our world and a world whose norms permit time- travel" (p.17).

The concept of time is one of the main issues which has been problematically proposed. What the Tralfamadorian life seems to describe, demystifies the issue. The following quotation enhances the point.

I am a Tralfamadorian, seeing all time as you might see a stretch of the Rocky Mountains. All time is all time. It does not change. It does not lend itself to warnings or explanations. It simply is. Take it moment by moment, and you will find that we are all, as I've said before, bugs in amber.( Vonnegut, 1969, pp.85-86).

As a matter of fact, time is ontologically problematized here. But the important point is that a postmodernist reading here does not lead to a resolution through flaunting Tralfamadore as the utopian world of "Time". We are just confronted with irresolvable questions. The following description ontologically foregrounds what the philosophy of time points out:

They were two feet high, and green, and shaped like plumber's friends. Their suction cups were on the ground, and their shafts, which were extremely flexible, usually pointed to the sky... the creatures were friendly, and they could see in four dimensions. They pitied Earthlings for being able to see only three. They had many wonderful things to teach Earthlings, especially about time. P.(26)

Another closely-related term which highlights the ontological level of Vonnegut's Slaughter-House five is "short circuit". Vonnegut has applied short circuiting in different parts of his novel. Here, the author himself acts as a "transworld identity" between the real world and the fictionalized world but we should bear in mind that he "fictionalizes himself" (p. 215). In one part of the novel, we come across some Americans who used latrines to relieve themselves, but unexpectedly we are confronted with the author:

Billy looked inside the latrine. The wailing was coming from in there. The welcome feast had made them as sick as volcanoes. The buckets were full or had been kicked over... in American near Billy wailed that he had excreted everything but his brains. Moments later he said, "there they go, there they go." He meant his brains. That was I , that was me. That was the author of this book (p. 125).

The interesting point concerning time is the way Tralfamadorians regard death. In their viewpoint "Death is a mundane entity owing to the four-dimensional outlook they possess as other-worldly creatures:

The most important thing I learned on Tralfamadore was that when a person dies he only appears to die. He is still much alive in the past, so it is very silly for people to cry at his funeral. All moments, past, present, and future, always have existed, always will exist. The Tralfamadorians can look at a all the different moments just the way we can look at Rocky Mountain, for instance. (p. 27)

Death has been emphatically foregrounded by the novel. The use of the phrase "so it goes" after each death description also problematizes the world of the dead and the world of the living." Postmodernist writing enables us to experiment with imagining our own deaths, to rehearse Our own deaths (McHale, 1983, p. 232), the problematization of the concept of time shows "the ontological boundary that we are all certain to experience " (p. 231). Tralfamadorian does not seem to be able to avoid the concept of death since he believes death is a predestined concept. This issue leads to another ontologically foregrounded issue being regarded as free will.

Billy Pilgrim says something about his death which triggers some ontological unanswered questions, he says, "I, Billy pilgrim, will die, have died, and always will die on February thirteen, 1976" (141, ch6). His comments point to a predestined situation in life: accordingly, the Tralfamodorians make a lot of ironic comments on Free will: "I've visited thirty-one inhabited planets in the universe, and I have studied reports on one hundred more. Only on Earth is there any talk of free wil' 'l. (Vonnegut, 1969, p. 86)

While ironically, we are invited to see "free will" as inaccessible on earth. From the very beginning, the concept of free will has been implicitly foregrounded because of the fact that all the events are foreshadowed ironically and more significantly the beginning and end of the novel as predestined qualities have been earmarked:

This one is a failure, and had to be, since it was written by a pillar of salt. It begins like this:

Listen:

Billy Pilgrim has come unstuck in time.

It ends like this:

Poo-tee-weet?(p.22)

When Billy was taken to Tralfamadore as a kidnapped Earthling, He “inquired at last: "why me?" and the Tralfamadorim reaction, as a result, stimulates the ontological preoccupations of literary readers in different perspectives. This is what they say in response to Billy's question:

That is a very Earthling question, to ask, Mr. Pilgrim why you? Why us for that matter? Why anything? Because this moment simply is. Have you ever seen bugs trapped in amber? ... "well, here we are, Mr. Pilgrim, trapped in the amber of this moment. There is no why.(pp. 76-77)

To make the problematization of fate harmonious with "psychological conceivability". The narrator gives an 
anecdote of an American prisoner of war who is punched in the mouth by a German soldier:

The American was astonished. He stood up shakily, spitting blood. He'd tow teeth knocked out. He had meant no harm by what he'd said evidently, had no idea that the guard would hear and understand "why me?" he asked the guard. The guard shoved him back into ranks . "Vy you? Vy any body?" he said.(p.91)

The last statement triggers the mind of the reader who confronts the same question in two different ontological situations and leads him/her to a philosophical problematization of fate and free will as subjectively constructed by human beings. That is to say, reality is just a human construct and a plurality of realities are "in confrontation" to denaturalize the concept of free will as authentic.

In Slaughterhouse-Five, the ontological dimension goes beyond the limitations and includes the taken-for-granted concepts of death, free will, Christianity and Bible, the story of Adam and Eve, biological characteristics of human beings and so forth to denote the fact that we are still very far away from knowledge and no single idea is right. The realization of Adam and Eve in different situations foregrounds the philosophical preoccupations of the novel with "the mode of existence," Billy once "stared into the patina of the corporal's boots' and saw Adam and Eve in the golden depth" (p. 53). The question of Adam and Eve as the source of existence leads Billy to the engagement with "where had he come from, and where should he go, now?" (p. 124). The structural pattern of Slaughterhouse- Five points to the fact that it has an ontology of it own which provides the readers with the capability to think about existence.

\section{Stream of Narration as a Technique in Slaughterhouse-Five}

Stream of narration is, as I pointed out before, mainly concerned with narrative conventions. It defies linearity and foregrounds the ontological world of the text as producing different meanings and interpretations by the readers. It no longer admits the consciousness of the individual author as authentic, but through its discontinuous portrait of the narrative technique, helps the readers to produce a variety of meanings to denaturalizes "narrative continuity" ( Hucheon, 1988, p.13). Vonnegut starts describing something, chooses a key point in that matter, elaborates on that key point so that the reader's mind is distracted, then he goes back to the issue at hand. In the first chapter the narrator is diegetically describing the process of writing his novel using realistic points, but all of a sudden, the process turns to be the reality of the text because he is revealed as one of the characters in the narrative of his novel:

One end of the wallpaper was the beginning of the story, and the other end was the end, there was all that middle part which was the middle,... The end, where all the lines stopped, was a beet field on the Ebbe, outside of Hall,... we were formed in ranks, with Russian soldiers guarding us-Englishmen, Americans thousand of us about to stop being prisoners of war.( Vonnegut, 1969, pp. 5-6)

The reader is shocked when he/she comes across the intrusion of the narrator himself into the narrative which is supposed to be written by him and ontologically the stream of narration shatters the boundary between illusion and reality in a problematizing situation.

In Slaughterhouse-Five, different layers of narration are juxtaposed, so that no single, linear, logical sequence of events can be traced. The reader is in a constant mood of suspense and uncertainty; some times, we may confront a sequentiality, but we are disillusioned as soon as the narrative itself is fragmented- such handling of narrative triggers the sense of undecidablity in Derridean terms and points to the fact that narrative itself is something arbitrary and pluralizes its interpretations in various situations based on the layer surfaced through the viewpoints of thoughtful readers.

Conventional narratology reflects harmonious minds and intellectual stability among readers. In postmodernist novels, narrative based on traditional norms is regarded as ideologically constructed and can not reflect the disordered and chaotic situation of man. In describing war, in Slaughterhouse-Five only a shattered and disintegrated narrative can fully transfer the sense of anxiety and disturbance to the readers.

Stream of narration shows that narrative techniques are not natural phenomena behind all literary masterpieces. In addition, one of the important functions of stream of narration in Slaughter house-Five is that it defies a specific plot, setting, characterization, or denouement in the novel. In chapter one, Vonnegut realistically says that:

I think the climax of the book will be the execution of poor old Edgar Derby, "The irony is so great. A whole city gets burned down, and then this one American foot soldier is arrested in the ruins for taking a teapot. And he's given a regular trial, and then he's shot by a firing squad.( p. 4)

The reader expects the climax of the narrative to be exactly the same, the event described here happens more or less, but this climax is never actualized since postmodernist narrative denaturalizes the notion of realistic climax as mundane and ideologically orientated. To defy the climax and to problematize the narrative, Vonnegut creates a stream of narration in which the events can not be logically related so much so that no beginning, middle or end can be traced to follow the climax and other narrotological aspects.

\section{Fragmentation}

In Slaughterhouse -Five, fragmentation as a postmodernist technique is obtained through a kind of schizophrenic dissociation of the thoughts and observations" of Billy Pilgrim "through whom we see the world". (Matz, 2004, p. 54) He constantly blends reality and illusion so that a single trend can not be observed in his descriptions. He mostly applies his schizophrenic mood to the context using time- travels. The noteworthy comment about postmodernist narrative is that fragmentation mostly reflects the fragmented and chaotic circumstances of postmodern man. Postmodernist novels 
make an effort to portray their fragmented narratives based on the above-mentioned criteria. They believe that they display reality as it is, disordered and simultaneously fragmented.

Narrative fragmentation is the best strategy in problematizing the traditional norms of plot, structure and time. Jason Dawley makes a precious comment as follows:

In the novel Slaughterhouse -Five, Kurt Vonnegut uses fragmentation of time, structure and character in order to unify his non-linear narrative. Vonnegut's main character, Billy Pilgrim travels back and forth in his own life span 'paying random visits to all events in between' (SF 23). The result is Billy's life is presented as a series of episodes without any chronological obligations (1).

Accordingly, what comes to the minds of the readers is a series of traditionally unrelated elements which open new horizons for the shocked readers and leave them with so many unanswered questions in a contradictory style.

Back to schizophrenia as a basic principle in postmodernist fragmentation, we can consider the effects of a suppressed childhood, war and a plane crash on Billy's split personality. Here, we do not encounter a realistic or even modernist characterization. Billy possesses fragments of both realist and modernist characters which are contradictorily existent in him. This quality leads us to uncertainty and suspense and directs our attention to the denaturalization of characterization as propagating metanarratives. The juxtaposition of his role as child, soldier, optometrist and parent completely disobeys the reader's expectations. R.D. Laing comes up with the following statements concerning what happens in a state of schizophrenia:

The person who has entered this inner realm... will find himself going, or being conducted... on a Journey... we respect the voyager, the explorer, the climber, the spaceman. (qtd . in Anja welling, p. 11)

In Slaughterhouse-Five "Billy either travels in time to Tralfamadore , or he is abducted by a flying saucer " (welling, p. 11) which gives an account of his schizophrenic situation.

Fragmentation does not just include fragmented narratives, it also includes pictures, graphs, and symbols. Montana Wildhack is the character to whom Billy makes love in the Tralfamadorian Zoo. She wears 'around her neck a silver chain with a heart-shaped locket hanging form it-between her breasts" (133). Later on, we observed a picture of chain with a locket on which something is carved as follows "God grant me the serenity to accept the things I can not change, courage to change the things I can, and wisdom to tell the difference'. (Vonnegut, 1969, p. 209)

In his office as an optometrist, Billy has the same prayer on the wall which expresses "his method for keeping going" (p. 60). Here the reader confronts a "dual-medium" text with different fragments here and there. McHale believes that this characteristic gives a kind of "simultaneity" to the text. "ideally their visual and verbal components should be "read" simultaneously' (1983, p.190) True simultaneity is unachievable in a verbal medium" but postmodernist narrative makes an attempt to reach its aim to some extent, Jason Dawley expresses some practical comments in this regard:

The use of fragmentation in Slaughterhouse-Five goes for beyond simply dividing the text into short sections. Vonnegut uses fragmentation to clarify Billy's character to illustrate the Tralfamadorians' time theory, and to maintain the Dreseden bombing as an ongoing atrocity. All these elements interweave in order to give uniformity to a text that, at first glance, seems to be going in all different directions. (3)

The important point here is that postmodern narrative has been implicitly stated by Tralfamadorians as theoric, because of fragmentations " there is no past, present or future in Slaughter-House Five". As Jason Dawley says the Tralfamadorian style of looking at universe is like looking at "a stretch of the Rocky Mountains ".That is to say, there is no beginning, no middle ore end in the post modernist novels as Rocky Mountains are viewed simultaneously without any fragments intervening with the view point.

Billy's schizophrenic state is widespread in the novel, even his own daughter Barbara thinks that he is going crazy, but his schizophrenia is ontologically problematized in the party where " the barbershop quartet of optometrist , "the Febs" sang "(172) Billy feels terribly sad here but he does not have any time travel or fragmented life after that. Later on he just associates the song with some of his bad experience self-consciously which is more paranoid than schizophrenic. But all in all "this is a novel in the telegraphic schizophrenic manner of tales of the planet Tralfamadore, where the flying saucers come from peace" (1)

\section{E. Parody as a Postmodernist Device in Slaughterhouse-Five}

As mentioned before, in this novel, we observe a parodic perspective of "science fiction" and war documentary" (Hutcheon, 1988, p. 44). This pattern is widely used in the structure of the narrative. The key point here is that none of these two generic qualities are preferred and no new form is rendered out of the two genres. What we get as readers, is the problematization of genres as metanarratives.

The blending of high and low literature in Slaughterhouse-Five causes uncertainty and suspension in the readers' mind. According to Anja welling in chapter one a woman who is a colleague of the narrator eats " a three musketeers candy Bar" which is an example of "high literature" the three musketeers was written by Alexander Duma, the same parodic pattern is observed in Billy's comrades including Roland Weary and two scouts who "called them selves 'the three musketeers"; but the point behind the above-mentioned examples is that Duma's masterpiece is eaten as a candy by a writer and his title is given to three foot soldiers not as a nostalgic view of the past but as an "ironic rethinking of the past"; Therefore, the notion of war is degraded and the suspicion of the open-minded readers who are shocked by the parody is increased. So much so that the realistic mode of previous eras is under estimated .Here, Patricia Waugh in 
Metafiction presents an argument which helps to underpin the ironic parody of realism:

Realism presents history as linear chronology, presents characters in the terms of liberal humanism, allows for the possibility of free will and responsible moral choice. But the novel implies that events like Dresden invalidate such liberal assumptions... Tralfamadore is, in fact, explicitly an aesthetic fantasy world premised upon a rejection of the philosophical and aesthetic assumptions underpinning realism. (1988, p. 128).

We can trace the ironic parody of realism all over the text. Even more surprisingly, modernism has been ironically parodied. In chapter one, the Love song of J. Alfred Prufrock has been parodied:

We saw waterfalls, too, streams jumping off cliffs into the valley of the Delaware. There were lots of things to stop and see and then it was time to go, always time to go. The little girls were wearing white party dresses and black party shoes, so strangers, would know at once how nice they were. 'Time to go, girls,' I'd say and we would go.( Vonnegut, 1969, p. 12)

The ironic viewpoint behind this parody which is based upon Eliot's poem, is, in my opinion, to defamiliarize the concept of war; I thinks what is aimed at is not the theme of the poem, but modernism itself has been shown as inadequate in portraying the concept of war, here, we can refer to what Russian formalists say as quoted by Patricia Waugh:

Parody develops out of the realization of the inadequacies of a certain convention. Not merely an unmasking of a non-functioning system, it is also a necessary and creative process by which new forms appear to revitalize the tradition and open up new possibilities (1988, p.50).

As was evident, modernism is not regarded as a "non-functioning system" but its placement in a new form "opens up new possibilities" in a defamiliarized and problematized situation in the postmodernist narrative.

\section{F. Metafictional Features of Slaughterhouse-Five}

Slaughter-House Five as a self-conscious, contradictory, pluralized and metafictional novel problematizes the realistic narrative forms to a high extent. But this is done through the ironic metafiction or "metafictional parody" (Waugh, 1988, p.67). The following example clarifies the issue:

As a trafficker in climaxes and thrills and characterization and wonderful dialogue and suspense and confrontations, I had outlined the Dresden story many times. The best outline I ever made, or anyway the prettiest one, was on the back of a roll of wallpaper. (p. 5)

Here, metafictional parody has been implicitly stated; a roll of paper dose not have a beginning, middle or end as postmodernist narrative does not follow any of the realistic techniques.

At the beginning of the narrative, the narrator says that "all this happened, more or less" (p.1). But, we, as readers are confused because of the fact that:

The book is defined as a novel, and a novel usually has the characteristic feature that it is fictitious. The first question the reader is confronted with is the question of truth. (Welling, p. 3)

In my opinion, here the realistic notion of "verisimilitude" as "the achievement of an illusion of reality in the audience" (Abrams, 1971, p. 211) has been problematized. In postmodernist fiction, the deconstructive aspect of narrative makes it possible for the reader, to read between the lines and to be notified of what Lennard Davis, as quoted by Hutcheon:

Novels do not depict life; they depict life as it is represented by ideology'. Ideology - how a culture represents itself to itself- 'doxifies' or naturalizes narrative representation, making it appear as natural or commen-sensical .(74)

In this novel, the interesting point is that the postmodern techniques themselves are expressed through the Tralfamadorian novels. The following excerpt would be more telling:

There are no telegrams on Tralfamadore... we Tralfamadorians read them all at once, not one after the other. There isn't any particular relationship between all the messages, except that the author has chosen them carefully, so that, when seen all at once, they produce an image of life that is beautiful and surprising and deep. There is no beginning, no middle, no end, no suspense no moral, no causes, no effects. What we love in our books are the depth of many marvelous moments seen all at one time. (2005, p. 88)

Here, two important points concerning postmodernist narrative have been metfictionally implied. The first point is the role of "simultaneity" (McHale, 1983, p.190) or reading everything at once through the four-dimensional outlook of Tralfamadorians. And the second point is the postmodernist non-linear outlook of plot.

The narrator also points to another aspect of postmodernism which can be the result of its antitotalizing manner in a metafictional manner:

There are almost no characters in this story, and almost no dramatic confrontations, because most of the people in it are so sick and so much the listless playthings of enormous forces. One of the main effects of war, after all, is that people are discouraged from being characters.(p. 164)

Accordingly, characters are fragmented and can not be read according to the traditional narrative techniques; they even defy modernist characterization; an important point is that "there is nothing intelligent to say about a massacre" (p.19) and the novel is doomed to be a "failure" (p. 22). So the narrative consciously portrays all these strategies to instigate the readers in problematizing all the so-called authentic concepts at the same.

\section{CONCLUSION}


In kurt Vonnegut's Slaughterhouse-Five, the ontological dimension is quite artistically foregrounded .The use of fictionalized world of Vonnegut and Tralfamadore as an imaginary world at the same time is a good example of what we have been thinking about as Earthlings We also encounter the outlook of the novel which is not epistemologically justified in the eyes of ordinary people.

Stream of narration which can be the counterpart of modernist stream of consciousness defies any narrative regulation and clearly puts the concept of narration into question .It points to the fact that narratives are ideologically constructed , and as Hutcheon has repeatedly emphasized the norms and authority are shown to be arbitrary .Therefore, the concept of denaturalization is brought up in this regard .Consequently ,stream of consciousness as proposed by modernism can not be objectively rendered through ideological narratives.

Fragmentation reflects the anxious, schizophrenic situation of Billy Pilgrim in the novel. It also reflects the way postmodernists regard life. They believe that mental fragmentation defies ideological narratives; even in modernism, individualism itself is made out of a dominant ideology which is deconstructively demystified through the postmodernist fragmented narratives.

Parody, as was pointed out before, "prolematizes the concept of originality" (Hutcheon, 1988, p.23) in postmodernism while the modernists regarded their literary works as original and noble .Parody is redefined as a literary device which deconstructs our belief in a unified literary system.

The concept of metafictionality self-consciously portrays the postmodernist view of narrative as human construction. It unravels the issue through using and abusing (ibid) realistic and even modernist narrative techniques to give us the opportunity to problematize the ideologically naturalized literary concepts. This aspect of postmodernism triggers the ontological dimension of literature as foregrounded in the intellectuality of the readers.

\section{REFERENCES}

[1] Abrams, M.H. (1971). A Glossary of Literary Terms. 3rd ed. New York and London: Halt, Rinehart and Winston, Inc.

[2] Dawley, Jason. "the Use of Fragmentation in Slaughterhouse-Five." <http://www.reocities.com/Hollywood//4953/kvFragmantation.html (accessed 20/1/2006).

[3] Hutcheon, Linda. (1988). A Poetics of Postmodernism. New York: Routledge.

[4] Hutcheon, Linda. (2005). The Politics of Postmodernism. London: Routledge.

[5] Lye, John. "Some Attribute of Modernist Literature." <http://www.brocku.ca/english/courses/2F55/modernism.html (accessed $18 / 2 / 2006)$.

[6] Lyotard, Jean Francois. (1984). The Postmodern Condition: A Report on Knowledge, Trans. Geoff Bennington and Brian Massumi. Minneapolis: University of Minnesota Press.

[7] Matz, Jesse. (2004). The Modern Novel: A Short Introduction. Malden, Mass: Blackwell.

[8] MacHale, Brian. (1983). Postmodernist Fiction. London: Routledge.

[9] Phillip, Leslie. "So It Goes. http://www.reocities.com/Hollywood/4953/kvsh5.html (accessed 1/3/2006).

[10] Vonnegut, Kurt. (1969). Slaughterhouse-Five. New York: Dell publishing co, Inc.

[11] Waugh, Patricia. (1988). Metafiction: The Theory and Practice of Self-conscious Fiction. London: Routledge.

[12] Welling, Anja. Discussion of Narrative Technique in Kurt Vonnegut's novel SlaughterhouseFive.http://www.heliweb.de/telic/welling.html.Wikipedia, the free encyclopedia (accessed 4/1/2006).

Noorbakhsh Hooti is currently an Assistant Professor of English Language and Literature at Kermanshah Razi University, Iran. $\mathrm{He}$ is a member of the research committee of the College of Humanities and Literature, Razi University. His main interests of research are drama, Short Story and Novel. He has been engaged in teaching English language and Literature for more than fifteen years. He holds Ph. D. in English Language and Literature, M. A. in English Language and Literature, and B.A in English Language and Literature. He has published a number of books, Research Projects, and articles in his areas of interest in academic journals.

Vahid Omrani is an instructor at Lorestan University, Khoram Abad, Iran. His main areas of research are Novel and drama. He holds a B. A. and M.A in English Language and Literature. 